\title{
ARTIKELEN
}

\section{Sociale innovatie: historie en toekomstperspectief}

\author{
Frank Pot ${ }^{*}$
}

\begin{abstract}
Sociale innovatie (en latere varianten daarvan als 'slimmer werken' en 'het nieuwe werken') heeft de afgelopen tien jaar een plek gekregen in het beleid van de sociale partners, overheid en veel ondernemingen, zowel in Nederland als in de Europese Unie. Op basis van documenten- en literatuurstudie wordt de wordingsgeschiedenis van het begrip in beleid en onderzoek besproken. Daaruit blijkt dat de door de verschillende partijen gebruikte definities sterk uiteenlopen. Het begrip sociale innovatie blijkt betrekking te hebben op het participatief en in onderlinge samenhang vernieuwen van arbeid, organisatie en personeelsbeleid om het functioneren van werkenden te verbeteren teneinde zowel de organisatieprestaties, de kwaliteit van de arbeid als de arbeidsrelaties op een hoger niveau te brengen. Een andere conclusie kan zijn dat het begrip sociale innovatie in de loop der jaren zodanig breed is geworden dat het lastig is samenhangende theorieën en integrale implementatiestrategieën te formuleren. Het dreigt een panacee te worden voor alle problemen van mens en organisatie. Toespitsing voor beleid en onderzoek is dus nodig. De belangrijkste onderzoeken in Nederland - met name van de EUR, het EIM en TNO geven positieve effecten aan voor sociaal innovatieve organisaties. De onderzoeken zijn echter onderling slecht vergelijkbaar, matig onderbouwd en geven geen of weinig aandacht aan de kwaliteit van de arbeid als effectvariabele. Een wetenschappelijk debat en meer onderlinge afstemming is gewenst.
\end{abstract}

\section{De beginjaren '80 en '90}

Sociale innovatie ('workplace innovation', 'innovative workplaces', 'innovative Arbeitsgestaltung', 'new world of work') is voor een aantal Europese landen een strategie om de eigen concurrentiepositie te verbeteren en de competenties van mensen te ontwikkelen. Werkgevers- en werknemersorganisaties trekken daarbij samen op. Sociale innovatie blijkt een rekbaar begrip te zijn. Elke stakeholder verstaat er weer net iets anders onder, waardoor verwarring ontstaat. Dit artikel beoogt inzicht te geven in hoe het begrip zich in Nederland heeft ontwikkeld in beleid en onderzoek, hoe het in Nederland en Vlaanderen is onderbouwd en hoe het zich verhoudt tot het EU-begrip 'social innovation'. Vervolgens worden de belangrijkste onderzoeken naar de effecten van sociale innovatie (van EUR, EIM,

* Frank Pot is emeritus hoogleraar van het Institute for Management Research van de Radboud Universiteit Nijmegen, f.pot@fm.ru.nl 
TNO) op hoofdlijnen besproken en wordt aangegeven wat de mogelijkheden en de beperkingen van deze onderzoeken zijn. Het artikel sluit af met een aantal evaluatieve opmerkingen.

Het begrip sociale innovatie raakt in de jaren tachtig in gebruik wanneer zowel wetenschap als beleid een koppeling maakt tussen discussies over innovatie enerzijds en over organisatieontwikkeling, personeelsbeleid en kwaliteit van de arbeid anderzijds. Het innovatiedebat ging toen vooral over wetenschap en technologie. De Innovatienota van de overheid van 1979 vermeldt weliswaar de mogelijke gevolgen van technologische innovatie voor de kwaliteit van de arbeid, maar niet de bijdrage die hoogwaardige arbeid aan innovatie kan leveren. De Sitter (1981) reageerde daarop met een onderbouwde stelling dat verbetering van de kwaliteit van de arbeid het 'broodnodige innovatievermogen' en de 'flexibiliteit van ondernemingen' kan vergroten.

In de discussies van toen speelde eveneens een wetenschappelijk debat over de stelling: 'Technologie determineert de arbeidsorganisatie en de functie-inhoud.' In een themanummer van $M \& O$ over vernieuwing van productieorganisaties (onder redactie van Van der Woude, 1982) trok men echter als conclusie: er is toch 'organisational choice', dus geen determinisme maar een zekere keuzevrijheid in organisatie- en functie-inrichting.

Deze inzichten benadrukken dat technologische en sociale innovatie onlosmakelijk met elkaar zijn verbonden. Sociale innovatie maakt namelijk het optimaal benutten van technologische innovatie (in die tijd vaak benoemd als automatisering) mogelijk en vergroot het innovatief vermogen van de organisatie. Deze gedachten over sociale innovatie zijn in die tijd onder meer te vinden bij consultants die bij Philips waren betrokken (Bolwijn et al., 1986). Zij beschreven het idee van een innovatieve firma die volgt op de flexibele firma. Ging de flexibele firma over integratie en decentralisatie, de innovatieve firma voegt daaraan participatie en democratisering toe. Met sociale innovatie bedoelen deze consultants 'alle niet-technische innovatie gericht op de concurrentiefactoren kwaliteit, flexibiliteit en innovativiteit' (persoonlijke mededeling Bolwijn, 2010). Om flexibel produceren te kunnen realiseren is het volgens hen van groot belang om de werknemers erbij te betrekken, hun functies te herontwerpen en ze bij te scholen. Ook voor het moreel van de werkenden is dat belangrijk: geen geïsoleerde arbeidsplaatsen en geen machinegebonden werktempo of korte cyclustijden (Bolwijn \& Kumpe, 1986).

\section{De introductie van welzijn en productiviteit}

In 1986 verscheen een boek van onderzoekers en adviseurs met als titel Sociale innovatie en automatisering (Vrooland et al., 1986). Vrooland gebruikt het begrip sociale innovatie als vervanging van het Duitse 'sozialgerechte Technologiepolitik': de verbinding van de kwaliteit van de arbeid met technologische vernieuwing. Welzijn en productiviteit zijn volgens de auteurs voortaan niet elkaars tegenpolen, maar dienen geïntegreerd een bijdrage te leveren aan de modernisering van de economische structuur. De Sitter (1981; 1986, pp. 20-22) noemt daar 
het tegenover elkaar zetten van productiviteit en welzijn 'een valse tegenstelling'. Deze gedachtegang sluit aan bij benaderingen uit de jaren '60 en '70 zoals de 'humanisering van de arbeid'. Ze is ook terug te vinden in innovatietheorieën als van Burns en Stalker (1961), die pleitten voor het samengaan van technologische ontwikkeling en nieuwe organisatievormen en die aangaven dat organisaties met een organische structuur in turbulente omgevingen succesvoller zijn dan organisaties met een mechanische structuur.

De Sitter (1981) baseerde zijn theorie op het onderzoek van Karasek (1978). Die onderscheidde in zijn 'job demand-control model' namelijk taakeisen of werkdruk versus beslisruimte of regelcapaciteit. De Sitter (1981) noemde dit 'het balansmodel'. Evenals Karasek benadrukte hij dat het niet de problemen zijn, die stress veroorzaken, maar de belemmeringen om ze op te lossen (De Sitter, 1981, p. 155). Een hoge werkdruk gecombineerd met een hoge regelcapaciteit levert 'actief werk' op met sociale en technische leermogelijkheden. Een hoge werkdruk met een lage regelcapaciteit is een stressrisico. Werk met lage taakeisen of weinig regelcapaciteit heeft nauwelijks leermogelijkheden. Er is in die gevallen sprake van onderbenutting van de competenties van mensen. Karasek noemde dat later 'verlies van innovatiepotentieel' (Karasek \& Theorell, 1990, p. 199) en gaf aan dat 'actief werk' ook de beste voorwaarde schept voor productiviteitsverbetering.

In de jaren ' 80 is de gedachte van een integrale theorie en aanpak niet alleen terug te vinden in het vakbondsbeleid ten aanzien van kwaliteit van de arbeid, maar ook in het discussieproject 'Anders Werken' (1981-1985) van de werkgeversorganisatie NCW en het FME-project Management en Arbeid Nieuwe Stijl (MANS, 1984-1988). Tevens ontstond in die periode een aantal adviesgroepen die zich in het verlengde van deze benadering met name richtten op het implementeren van autonome taakgroepen.

Ook in het overheidsbeleid gebruikte men in die periode het begrip sociale innovatie. De Arbeidsinspectie entameerde begin jaren negentig het project 'Sociale Innovatie Zeehavens'. Sociale innovatie is hier: 'verbetering van functie-inhoud en organisatie van het werk, primair vanuit een oogpunt van kwaliteit van de arbeid, maar mede gericht op een grotere beheersbaarheid en flexibiliteit van het productieproces' (Peeters \& Pot, 1992). Het ministerie van Sociale Zaken en Werkgelegenheid liet een instrument ontwikkelen - vooral op basis van theorieën van De Sitter en Karasek - om welzijn bij de arbeid (WEBA) te meten en te bevorderen. Hiermee is het 'welzijnsartikel' (art. 3) in de toenmalige Arbeidsomstandighedenwet geoperationaliseerd (Projectgroep WEBA, 1989). Daarnaast vond operationalisatie van het welzijnsartikel plaats door het opstellen van ergonomische criteria, die ook goed geacht werden te zijn voor de productiviteit én voor de gezondheid van werknemers.

De eerste systematische verhandeling over het begrip sociale innovatie is te vinden in de inaugurele rede van Looise (1996). Hij omschrijft sociale innovatie als: 'de bewuste introductie en toepassing binnen een rol, groep, organisatie of maatschappelijk verband van ideeën, maatregelen of procedures met betrekking tot de inbreng van mensen, die nieuw zijn voor de betreffende unit en die ontworpen zijn om een belangrijk voordeel op te leveren voor het individu, de groep, de organisatie of de maatschappij'. Samenhangend met deze omschrijving besteedt 
Looise veel aandacht aan participatie en medezeggenschap. Hoewel Looise alleen het organisatieniveau uitwerkt geeft hij aan dat sociale innovatie zich ook kan afspelen op maatschappelijk niveau. Daarmee is zijn definitie breder dan die van Bolwijn et al. (1986), Vrooland et al. (1986) en de Arbeidsinspectie (Peeters \& Pot, 1992).

\section{Doorbraak in het begin van de 21e eeuw}

De echte doorbraak van het gebruik van het begrip sociale innovatie kan gesitueerd worden rond 2005, met als opmaat het begrip 'slimmer werken'. Dat concept werd uitgewerkt in het Platform Slimmer Werken waarin participeerden de AWVN, CNV BedrijvenBond, De Unie en FNV Bondgenoten, met de Erasmus Universiteit en TNO als adviseurs. Men realiseerde zich dat demografische ontwikkelingen (veroudering en ontgroening van de werkende bevolking) en globalisering het noodzakelijk maakten om competenties beter te benutten en de arbeidsproductiviteit te verhogen. In de Stichting van de Arbeid (2005) werd het onderwerp 'arbeidsproductiviteit' weer bespreekbaar. Als basis gebruikte het Platform het zogenaamde TOP-model van TNO Arbeid, dat gebaseerd is op de sociotechniek van De Sitter en het 'job demands-control model' van Karasek: een driehoek van Technologie, Organisatie en Personeel (TOP). Slimmer werken is dan het verbeteren en slimmer verbinden van genoemde drie elementen. Doel is 'verbeteringen of vernieuwingen toepassen zodat de kwaliteit van de diensten of producten en de arbeidsproductiviteit op niveau blijven of toenemen, zonder noemenswaardige kostenstijging en met een beheersing van werkstress en fysieke belasting' (Jongkind et al., 2003; Vink, 2002; Vaas, 2001). Niet harder maar slimmer werken, was het adagium. Er kwam een gezamenlijke publicatie van de sociale partners (De Bruin et al., 2004). En de AWVN kwam in hetzelfde jaar ook nog met een eigen 'Manifest Sociale Innovatie'. De AWVN gebruikt 'sociale innovatie', 'slimmer werken' en 'investeren in mensen' door elkaar. In dit gezelschap groeide het idee dat er een 'kennis- en actiecentrum sociale innovatie' zou moeten komen. Binnen het Innovatieplatform werd het belang van sociale innovatie onderkend.

Uit de data van de Erasmus Concurrentie \& Innovatie Monitor 2005 (Volberda et al., 2006) bleek dat sociale innovatie een groot deel van het innovatiesucces verklaart, althans dat er sprake is van een sterke correlatie. Dat maakte veel indruk op de beleidsmakers en anderen. Er werd door de ministeries van EZ, OCW en SZW een Taskforce Sociale Innovatie ingesteld die in 2005 met een rapport kwam. Sociale innovatie was daarin: 'het vernieuwen van de arbeidsorganisatie en het maximaal benutten van competenties, gericht op het verbeteren van de bedrijfsprestaties en ontplooiing van talent' (Taskforce, 2005). De Erasmus Universiteit (Volberda et al., 2006) benadrukte daarnaast nog het management en de samenwerking tussen bedrijven (in de keten en/of in open innovatie). De vakbonden voegden eraan toe dat sociale innovatie ook tot meer werkplezier zou (moeten) leiden.

Vertegenwoordigers van kennisinstellingen en het Innovatieplatform maakten een voorstel voor een 'kennis- en actiecentrum sociale innovatie' 
(Volberda et al., 2005). In het Innovatieplatform werd benadrukt dat het vooral een actiecentrum zou moeten zijn dat kennis verspreidt, maar niet zelf ook onderzoek doet. Hieruit ontstond in 2006 het Nederlands Centrum voor Sociale Innovatie, dat een brede definitie hanteert waarin de bovenstaande definities kunnen worden herkend, ook het werkplezier en de medezeggenschap. 'Het NCSI wil bijdragen aan verhoging van de arbeidsproductiviteit, betere benutting van talenten binnen organisaties en meer werkplezier.' Het NCSI doet dat door het stimuleren en initiëren van 'innovaties op het terrein van management, organisatie en arbeid'. Het 'vernieuwen van arbeidsrelaties' werd daar later aan toegevoegd. Eveneens in 2006 kwam de SER met het advies 'Welvaartsgroei voor en door iedereen'. Daarbij zit een thematische uitwerking van sociale innovatie van 60 pagina's. De SER sloot voor 'slimmer werken' aan bij een model van TNO, nam voor sociale innovatie de definitie van de taskforce over en voegde daar de gedachte aan toe dat sociale innovatie ook tot grotere werknemerstevredenheid en duurzame participatie kan leiden (SER, 2006). Met dit advies en met het NCSI stond sociale innovatie op de kaart van Nederland. Sociale partners spelen daarin een grote rol, zoals dat overigens ook in andere landen (EESC, 2011) het geval is. Ondernemingen, instellingen, platforms, ministeries, provincies, bedrijfstakorganisaties, hogescholen en universiteiten hebben het onderwerp op de agenda gezet.

In het jaar 2007 rekenden sociale partners in Nederland onder sociale innovatie: meer samenwerking in arbeidsverhoudingen, flexibel organiseren (slimmer werken, maar vooral arbeidstijdenmanagement en kunnen zelfroosteren), gezondheidsmanagement, employability (vooral leeftijdsbewust personeelsbeleid) en resultaat gericht belonen (Pot et al., 2008), waarbij resultaatgericht belonen vooral van werkgeverszijde werd ingebracht. Sommigen waren van mening dat met dit rijtje sociale innovatie te veel een zaak van HR-managers wordt, terwijl kringen van HR-wetenschappers juist betoogden dat de beleidsstukken over sociale innovatie de rol van HRM ontkennen of onderbelichten (Looise \& Nijhof, 2006). Hoe dan ook, is er de laatste jaren steeds meer nadruk komen te liggen op vernieuwing van de arbeidsrelatie, de relatie tussen medewerker en baas (Nauta et al., 2007; Nauta, 2011).

Een andere variant van sociale innovatie is 'Het Nieuwe Werken' (HNW), het vervolg van 'telewerken' of 'thuis werken'. Deze ontwikkeling startte halverwege de jaren negentig en heeft de laatste jaren een grote vlucht genomen. Het accent ligt op tijd- en plaatsonafhankelijk werken. Het initiatief kwam uit de hoek van het gebouwenmanagement: kostenbesparing door kleinere kantoren. Later kwamen daar bij het verminderen van reistijd, files en $\mathrm{CO}_{2}$-uitstoot, een betere balans tussen werk en privé en nog weer later het aansluiten bij de 'werknemer 2.0'. Al snel was duidelijk dat dit niet alleen over gebouwen ging, maar ook over een andere managementstijl, een andere arbeidsorganisatie en een andere arbeidsrelatie. De begrippen sociale innovatie en HNW worden de laatste tijd vaak door elkaar gebruikt.

In datzelfde jaar 2009 werden de gevolgen van de kredietcrisis en de economische crisis zichtbaar. Dat heeft echter niet vertragend gewerkt op de verbreiding van 
sociale innovatie. Integendeel, de AWVN organiseerde een seminar onder de titel: Sociale innovatie, juist nu!

Vanaf 2009 is de discussie over sociale innovatie beïnvloed door het politieke besluit om de AOW- en pensioenleeftijd te verhogen naar 67 jaar. Veel seminars en congressen richten zich daarop. Het belang van sociale innovatie wordt meer dan ooit onderkend en sociale innovatie ontwikkelt zich bijna tot synoniem voor 'duurzame inzetbaarheid'.

\section{Sociale innovatie in de publieke sector}

De begrippen 'slimmer werken' en 'sociale innovatie' zijn het eerst omarmd door het private bedrijfsleven, maar worden inmiddels ook toegepast in publieke sectoren zoals het onderwijs, de zorg en het openbaar bestuur. In alle drie sectoren wordt gesproken over 'meer ruimte voor de professional'.

Het Sectorbestuur Onderwijsarbeidsmarkt (Van der Meer et al., 2008; Netwerk Onderwijsinnovatie, 2010) geeft de volgende definitie: 'Slimmer werken in het onderwijs is het aanbrengen van verbeteringen of vernieuwingen die betrekking hebben op het werkproces van personeel in het onderwijs en waarbij de leeropbrengsten van de leerlingen (kennis, vaardigheden $\&$ attitude) op niveau blijven of toenemen en die duurzame opbrengsten voortbrengen voor de schoolorganisatie én het onderwijspersoneel.' Hier is dus het element 'duurzaam' toegevoegd.

Het Zorginnovatieplatform (2009) omschrijft sociale innovatie als het 'optimaliseren van arbeidsorganisatie en inzetbaarheid'. Als instrumenten noemt het Platform: 'zelfroosteren, zelfsturing, taakherschikking, functiedifferentiatie en goede arbeidsomstandigheden'.

Het ministerie van BZK ten slotte heeft een Stuurgroep Slimmer Werken onder leiding van de secretaris-generaal opgericht. Op het congres 'Slimmer werken loont' van 12 mei 2010 benadrukte de sg dat dit geen verkapte bezuinigingsactie is om meer te doen met minder mensen. 'Het gaat vooral over met plezier naar je werk gaan en je werk beter kunnen doen.'

\section{Vlaanderen}

In hetzelfde jaar dat het NCSI van start ging (2006) begon in Vlaanderen het programma 'Flanders Synergie, innovatie van werk en organisatie'. Initiatiefnemers waren de Vlaamse overheid, de KU Leuven, het Agentschap van het Europees Sociaal Fonds (ESF) en de adviesbureaus Panta Rhei en ST-groep. 'Als complement van technologische en productinnovatie willen wij sociale innovatie zien als innovaties in de sfeer van de arbeidsorganisatie', zo stelde het handboek van het programma (Hootegem et al., 2008, p. 14). Het handboek maakt verderop een onderscheid tussen 'organisatorische innovatie' (organisatieniveau: anders organiseren) en 'sociale innovatie' (werkplek-/functieniveau: beter werken, werkbaarheid, kwaliteit van de arbeid). Aan de kwaliteit van de arbeid worden vier dimensies onderscheiden: de arbeidsinhoud, de arbeidsomstandigheden, de arbeidsvoorwaarden en de arbeidsverhoudingen. Het handboek geeft een theore- 
tische onderbouwing van de samenhang tussen organisatieniveau en werkplek-/ functieniveau met behulp van de sociotechniek van De Sitter en zijn navolgers. De benadering van de 'arbeidsinhoud' wordt onderbouwd met het 'job demandcontrol model' van Karasek en met het eerder genoemde WEBA-instrument (Hootegem et al., 2008, pp. 86-93). Het handboek geeft ook veel 'tools' voor diagnose en verandering. Vanwege de uitstekende theoretische onderbouwing, de praktische aanwijzingen en de gereedschappen is dit handboek de beste onderbouwing van (een programma van) sociale innovatie in Europa. In 2010 is in Vlaanderen een kleine organisatie in het leven geroepen, vergelijkbaar met het NCSI, namelijk 'Flanders Synergie en Competentiepool Innovatieve Arbeidsorganisatie'.

\section{De Europese Unie}

Looise (1996) gaf aan dat sociale innovatie ook betrekking kan hebben op maatschappelijke problemen. In het project Economie van de $21^{\text {ste }}$ Eeuw (Leijnse, 2002) werd 'het combineren van werken, zorgen en leren tijdens de levensloop' aangeduid met de term 'het nieuwe werken'. Hier wordt het begrip dus verbreed van werk naar zorgen en leren.

Een breed begrip wordt ook gebruikt door de EU, die de laatste jaren het begrip 'social innovation' heeft omarmd (Europese Commissie, 2010a, 2010b, 2010c). In maart 2011 werd 'Social Innovation Europe' gelanceerd. Het gaat om maatschappelijke problemen die niet vanzelf of niet alleen door markten of technologische innovatie worden opgelost (armoede, gezond ouder worden, milieu etc.) en waarvoor ook nieuwe gedragingen, samenwerkingsverbanden, institutionele arrangementen en sociaal ondernemerschap nodig zijn. Dragers van de verandering worden burgers, ngo's en sociale ondernemers geacht te zijn. Inmiddels heeft 'social innovation of work and employment' zich een vaste plek verworven op EUcongressen over 'social innovation' (Pot et al., 2012).

Vanwege de begripsverwarring is het voor Nederlanders en Vlamingen lastig om het begrip sociale innovatie in het buitenland te gebruiken. De meesten van hen kiezen voor 'workplace innovation', sommigen voor 'management innovation'. Het begrip 'workplace innovation' (of 'innovative workplaces') sluit aan bij de titels van de nationale programma's in Finland, UK, Ierland en Duitsland (Totterdill et al., 2009) en wordt ook gebruikt door het European Economic and Social Committee (werkgevers, vakbonden en ngo's, EESC, 2011) en de OECD (2010).

Verwacht mag immers worden dat sociale innovatie een bijdrage kan leveren aan de kerndoelstellingen van de EU-2020 Strategy: 'smart, inclusive and sustainable growth'. De link met kwaliteit van de arbeid wordt vooral benadrukt door het EESC (2011) en het Europees Agentschap voor Veiligheid en Gezondheid op het Werk (Eeckelaert et al., 2012).

\section{Een poging tot ordening van een uitdijend begrip}

Met het gebruik van het begrip sociale innovatie werd ooit benadrukt dat dit een aanvulling moet zijn op technologische innovatie. Het was niet bedoeld als con- 
Tabel 1 Dimensies van sociale innovatie

\begin{tabular}{|c|c|c|c|}
\hline $\begin{array}{l}\text { Context (aanleidin- } \\
\text { gen) }\end{array}$ & Verandergebieden & Output (doelen) & Outcome \\
\hline $\begin{array}{ll}\text { - } & \text { (Dreigend) perso- } \\
\text { neelstekort } \\
\text { - } \\
\text { Mondiale concur- } \\
\text { rentie } \\
\text { Kenniseconomie } \\
\text { Benutten techno- } \\
\text { logische innovatie } \\
\text { Noodzaak kosten- } \\
\text { besparing } \\
\text { Milieuvervuiling } \\
\text { Nieuwe arbeids- } \\
\text { verhoudingen }\end{array}$ & $\begin{array}{ll}\text { - } & \text { Arbeidsorganisatie } \\
\text { - } & \text { Besturingsstruc- } \\
\text { - } & \text { Puur } \\
\text { - } & \text { Sersoneelsbeleid } \\
& \text { en stijl van leiding } \\
& \text { geven } \\
\text { - } & \text { ICT ondersteuning } \\
\text { - } & \text { Werkplek en } \\
& \text { gebouw } \\
\text { - Arbeidsvoorwaar- } & \text { den } \\
\text { - Samenwerking in } \\
\text { de keten en open } \\
\text { innovatie }\end{array}$ & $\begin{array}{l}\text { - } \quad \text { Arbeidsproduc- } \\
\text { tiviteit } \\
\text { Kwaliteit van de } \\
\text { arbeid: minder } \\
\text { stressrisico's en } \\
\text { fysieke belasting; } \\
\text { leermogelijkhe- } \\
\text { den } \\
\text { 'Volwassen' } \\
\text { arbeidsrelatie en } \\
\text { betrokkenheid }\end{array}$ & $\begin{array}{ll}\text { - } & \text { Innovatief ver- } \\
& \text { mogen } \\
\text { - } & \text { Concurrentie- } \\
\text { kracht } \\
\text { - } \\
\text { Financiële resul- } \\
\text { taten } \\
\text { - Werkplezier } \\
\text { - Duurzame inzet- } \\
\text { baarheid } \\
\text { Lager ziektever- } \\
\text { zuim } \\
\text { Arbeidsparticipa- } \\
\text { tie } \\
\text { Minder files, reis- } \\
\text { tijd, } \mathrm{CO}_{2} \text {-uit- } \\
\text { stoot }\end{array}$ \\
\hline
\end{tabular}

trastbegrip van asociale innovatie of van economische innovatie (business innovation) al duiken die associaties regelmatig op.

Er heeft zich een begrip sociale innovatie ontwikkeld dat vanwege theoretische, politieke en praktische argumenten steeds breder wordt en steeds meer gaat omvatten. Daarbij is meestal niet duidelijk of de in de definitie gevatte dimensies allemaal tegelijk moeten voorkomen om over sociale innovatie te kunnen spreken (én/én) of dat één dimensie daarvoor ook al genoeg is (óf/óf).

Sociale innovatie in de genoemde definities verwijst naar interventies (processen) en/of gerealiseerde interventies (uitkomsten).

Binnen een bepaalde context (1) die aanleiding is voor een interventies, worden bepaalde verandergebieden (2) vastgesteld, gericht op bepaalde doelen, ofwel de output (3) en doelen waaraan deze output weer een bijdrage levert, de outcome (4). Tabel 1 geeft praktische voorbeelden van deze vier dimensies. Interventies zijn in tabel 1 niet opgenomen; dat zou een te lange lijst opleveren.

De breedte van het begrip maakt duidelijk dat de samenhang niet meer in één theorie valt te vatten, dat zich bij het onderzoek veel methodologische problemen voordoen en dat het moeilijk is bij ontwerp en ontwikkeling een integrale aanpak te formuleren. Het begrip is zo breed geworden dat het een panacee lijkt voor alle problemen van mens en organisatie. Zowel voor beleid als voor onderzoek doet men er echter verstandig aan om uit die brede definities die elementen te kiezen waar men echt iets mee wil en waarvan de samenhang theoretisch kan worden onderbouwd. Eenieder moet zijn eigen definitie dus expliciteren.

Samenvattend kan worden gezegd dat het begrip sociale innovatie betrekking heeft op het participatief en in onderlinge samenhang vernieuwen van arbeid, organisatie en personeelsbeleid om het functioneren van mensen te verbeteren teneinde zowel de organisatieprestaties, de kwaliteit van de arbeid als de arbeids- 
relaties op een hoger niveau te brengen. Dit zal uiteraard bijna altijd ook in samenhang met technologische innovatie gebeuren.

In de meeste omschrijvingen van sociale innovatie en het nieuwe werken wordt ook aangegeven hoe het ontwerp- en implementatieproces eruit zou moeten zien. Kern daarvan is dat medewerkers en hun direct leidinggevenden erbij worden betrokken of zelf het initiatief nemen. Een theoretische onderbouwing daarvoor kan gevonden worden bij Lammers (1967) die aangaf dat - vrij vertaald - 'macht delen' geen 'zero-sum-game' is, maar dat de totale macht van de organisatie vergroot kan worden. Uit evaluatieonderzoek in het Finse programma sociale innovatie blijkt dat in de organisaties die positieve effecten lieten zien ten aanzien van zowel organisatieprestaties als kwaliteit van de arbeid, medewerkers waren betrokken bij ontwikkeling en implementatie van de interventies. Organisaties die op beide uitkomsten negatief scoorden, bleken de projecten top-down aangepakt te hebben (Ramstad, 2009).

\section{Onderzoek naar sociale innovatie}

Hoe proberen onderzoeksgroepen het begrip sociale innovatie in te perken om het onderzoekbaar te maken? Dit artikel behandelt alleen de hoofdlijnen. De EUR, het EIM en TNO hebben grootschalig onderzoek naar sociale innovatie gedaan en beogen dat in de vorm van een monitor regelmatig te herhalen. Kleinschalige onderzoeken naar sociale innovatie en het nieuwe werken blijven hier buiten beschouwing.

Onderzoekers van de Rotterdam School of Management (Erasmus Universiteit, 2009) geven aan dat het bij sociale innovatie gaat om de niet-technologische determinanten van innovatie. Zij hanteren in hun Erasmus Concurrentie en Innovatie Monitor sinds 2005 de volgende definitie. Sociale innovatie is:

- het ontwikkelen van nieuwe managementvaardigheden (dynamisch managen),

- het hanteren van innovatieve organisatievormen (flexibel organiseren),

- het realiseren van hoogwaardige arbeidsrelaties (slimmer werken) en hoogwaardige samenwerkingsverbanden (externe samenwerking) om

- het concurrentievermogen en de productiviteit te verbeteren.

Het achterliggende idee is dat deze factoren vooral van belang zijn voor het vermogen om nieuwe kennis te absorberen. Als uitkomstmaten gebruikt de EUR: omzetgroei, winstgroei, innovatie, productiviteit, aantrekken van nieuwe klanten, groei van marktaandeel en reputatie. Er worden geen uitkomstmaten gebruikt op het gebied van kwaliteit van de arbeid, vanaf 2010 wél 'werknemerstevredenheid'. In de Monitor van 2010 vulden 923 bedrijven de vragenlijst in, wat overeenkomt met een respons van $9 \%$. De meest uitvoerige theoretische onderbouwing van de monitor is te vinden in het document waarin wordt gepleit voor een 'kennis- en actiecentrum sociale innovatie' (Volberda et al., 2005). Die onderbouwing sluit voor een belangrijk deel aan bij benaderingen die worden aangeduid met 'Resource Based View' (RBV) of 'Dynamic Capabilities'”. 
De EUR-monitor laat interessante uitkomsten zien: sociaal innovatieve bedrijven scoren hoger dan niet-sociaal innovatieve bedrijven op alle prestatie-indicatoren en innovatiesucces wordt voor $75 \%$ verklaard door sociale innovatie, voor $25 \%$ door technologische innovatie. De Erasmus-monitor heeft veel invloed in de zin dat de uitkomsten ervan vaak worden geciteerd. Des te meer mag worden betreurd dat er in al die jaren nog geen methodologische verantwoording is gepubliceerd. Zelfs de vragenlijst is niet beschikbaar voor geïnteresseerden. Daardoor valt moeilijk te beoordelen wat de kwaliteit van het onderzoek is ${ }^{2}$ en wat de in de Nederlandse rapporten gepresenteerde resultaten precies betekenen (Volberda et al., 2006; Erasmus Universiteit, 2009 en 2010; Volberda et al., 2011). Weliswaar verwijzen de onderzoekers naar hun internationale publicaties in 'peerreviewed' tijdschriften, maar die gaan over beperkte onderdelen van de monitor zoals de heterogeniteit van managementteams en exploratie of exploitatie of beide, en lichten derhalve slechts een tipje van de sluiter op betreffende de verantwoording van variabelen, hypothesen en analysemethoden (bijvoorbeeld Alexiev et al., 2010; Vaccaro et al., 2012).

Het EIM (Van der Hauw et al., 2009) gaf zonder theoretische overwegingen in zijn door het Innovatieplatform gevraagde onderzoek naar het voorkomen van sociale innovatie in het mkb een brede definitie van sociale innovatie als ook een smalle die 'slimmer werken' werd genoemd. Het achterliggende idee is dat het bij sociale innovatie gaat om het productiever maken van bedrijven, om onderscheid met technologische innovaties, ICT-innovaties en productinnovaties en om een breder begrip dan 'organisatorische innovatie'. De opbrengsten van sociale innovatie worden breder bezien dan alleen productiviteit. Het EIM keek ook naar de relatie van sociale innovatie met het bedrijfsresultaat, de omzet en de werkgelegenheid, echter niet de kwaliteit van de arbeid omdat die volgens de auteurs niet primair gericht is op productiviteit (Van der Hauw et al., 2009). Hoe het onderzoek is uitgevoerd en hoe men tot conclusies komt, is in het rapport goed onderbouwd. Bij 650 bedrijven met 5-250 medewerkers is een telefonische enquête afgenomen.

Wat betreft de onderzoeksresultaten is vermeldenswaard dat sociale innovatie in het mkb correleert met ondernemingsprestaties en ook samengaat met meer werkgelegenheid. Recentelijk heeft het EIM een haalbaarheidsonderzoek naar een monitor sociale innovatie voor het mkb gepubliceerd (Winnubst et al., 2011). Het EIM heeft concepten daarvan voorgelegd aan onderzoekers van andere onderzoeksinstellingen.

TNO (bijv. Oeij et al., 2010a) benadrukt bij sociale innovatie en 'slimmer werken' de interventies op het vlak van technologie, organisatie en personeel (het TOPmodel). Het achterliggende idee is dat sociale innovatie positief is voor zowel organisaties als medewerkers en behalve tot organisatieprestaties ook tot meer werkplezier leidt. De basis voor die verwachting ligt in een model dat voortkomt uit de sociotechniek en het 'job demand-control model' van Karasek \& Theorell (1990). Sociale innovatie definieert TNO in haar laatste publicatie (Oeij et al., 2010 a, p. 24) als: 'een strategisch ingegeven vernieuwing op het terrein van organiseren en/of organisatiegedrag, c.q. gedrag in organisaties, en is op te vatten als een vermogen van een organisatie'. Bij het operationaliseren van de definitie 
maken de auteurs vooral gebruik van de Resource Based View (RBV). De kwaliteit van de arbeid krijgt minder aandacht dan in eerdere benaderingen van TNO en is beperkt tot ziekteverzuim.

TNO baseert onderzoek naar en publicaties over sociale innovatie veelal op de tweejaarlijkse WEA (de Werkgevers Enquête Arbeid). Van de WEA bestaat een uitvoerige methodologische verantwoording, waarin begrippen, schalen, vragen, steekproef- en analysemethoden aan de orde komen (Oeij et al., 2010b; Oeij et al., 2011). Een beperking van de WEA is dat deze niet ontworpen is om sociale innovatie en de effecten daarvan te meten. De co-financier van deze monitor, het ministerie van SZW, heeft daarmee namelijk een bredere doelstelling. Een aantal variabelen uit de WEA wordt aangemerkt als indicatoren voor sociale innovatie en alleen organisaties met tien of meer medewerkers worden in de substeekproef sociale innovatie betrokken (2008: 2.263 bedrijven en instellingen, wat overeenkomt met een respons van 35\%). Op basis van de Resource Based View (RBV) worden door TNO vier dimensies van sociale innovatie onderscheiden: strategische oriëntatie, flexibel werken (interne en externe flexibiliteit; maatwerk in arbeidsrelaties), slimmer organiseren en product-marktverbetering. Sociaal innovatieve organisaties scoren volgens het TNO-onderzoek beter dan niet sociaal innovatieve organisaties op organisatieprestaties (arbeidsproductiviteit, omzet, winst) maar onderscheiden zich niet op het vlak van ziekteverzuim (Oeij et al., 2010a; Oeij et al., forthcoming). Dat lijkt niet verwonderlijk want sociale innovatie is meestal niet gericht op de reductie van ziekteverzuim. Dat kan hoogstens een indirect effect zijn.

\section{Evaluatie van het onderzoek}

Het is duidelijk dat de drie onderzoeksoperationalisaties van het begrip sociale innovatie (door de EUR, het EIM en TNO) ons nog geen houvast bieden. Daarvoor zijn ze te verschillend. Een gemis is dat 'kwaliteit van de arbeid' als effectvariabele ontbreekt. Hoopgevend is dat de overlap van (sub)dimensies groot is. Het gaat vaak over ongeveer dezelfde onderwerpen, maar soms ook juist niet. Een voorbeeld daarvan is dat de EUR bij 'flexibel organiseren' de volgende subdimensies onderscheidt: differentiatie van innovatie en efficiency op verschillende bedrijfslocaties, horizontale samenwerking en kennisdeling, gedeelde besluitvorming, informele netwerken. TNO meet onder 'flexibel werken': bredere inzetbaarheid van personeel, flexibele werktijden, flexibele contracten, zelf roosteren, maatwerk werktijden, maatwerk werkprestaties, ontwikkeling/opleiding van medewerkers, flexibele inzet van medewerkers. De theoretische afleidingen van de dimensies zijn over het algemeen nog zwak of ontbreken. Dit maakt het onderzoek naar sociale innovatie wetenschappelijk kwetsbaar en beleidsmatig niet sterk.

Inhoudelijk gezien, kan geconcludeerd worden dat sociale innovatie, in alledrie de onderzoeksdefinities, tot betere prestaties van de organisatie leidt (Van der Hauw et al., 2009; Oeij et al., 2010a; Volberda et al., 2011). In de meeste onderzoeken in andere Europese landen wijst onderzoek er eveneens op dat sociale innovatie tot betere prestaties van de organisaties leidt. Waar dat gemeten is blijkt vaak ook de 
kwaliteit van de arbeid beter te worden (Pot \& Koningsveld, 2009; Pot, 2011). Bureau Bartels (2011) evalueerde in opdracht van het ministerie van SZW 49 Nederlandse projecten rond sociale innovatie (vooral slimmer werken), die in 2009 met ESF-subsidie waren uitgevoerd. De conclusie was dat de effecten vooral betrekking hadden op meer afwisseling en verdieping in het werk, een beter beeld of imago van de organisatie bij de werknemers en meer mogelijkheden voor de benutting van de competenties en de vaardigheden van de werknemers. Een verbetering van de kwaliteit van de arbeid kwam vooral tot uitdrukking door een grotere betrokkenheid van de werknemers, meer inspraak van hen en meer autonomie in het werk (Bureau Bartels, 2011, p. iii).

Vervolgens zijn er nog allerlei methodologische vraagstukken aan de orde. Een vraag is bijvoorbeeld of gezocht wordt naar het effect van afzonderlijke variabelen of naar het effect van meerdere variabelen (Delery \& Doty, 1996). Of moeten we ons juist richten op hoe verschillende stakeholders met structurele dilemma's omgaan (Prud'homme \& Dankbaar, 2009)? Tevens is een vraag welke verhouding tussen surveys en casestudies de meeste kennis oplevert. Deze ongemakkelijke situatie wordt ook door een aantal onderzoekers onderkend. Het nu vierjarige samenwerkingsverband 'INSCOPE research for innovation' van de Erasmus Universiteit, de Universiteit Maastricht, Universiteit van Amsterdam, TNO en de Universiteit Twente heeft op dit vlak helaas geen rol gespeeld. Een initiatief van een aantal lectoren om onderzoekers van universiteiten, TNO, EIM en hogescholen hierover (en over de adviespraktijk) met elkaar van gedachten te laten wisselen teneinde tot betere modellen en methoden en tot meer afstemming te komen, is na enkele bijeenkomsten verzand.

\section{Toekomstperspectieven}

Het NCSI houdt per 1 april 2012 op te bestaan. Het is altijd bedoeld geweest als een tijdelijke aanjager van activiteiten. Op het slotevent in maart zal aan de orde komen wat er is bereikt. Sociale innovatie en het nieuwe werken zijn niet meer weg te denken in Nederland. Sociale partners benadrukten dat in het manifest 'Naar nieuwe arbeidsverhoudingen' van januari 2011. Het kabinet geeft in zijn bedrijvenbeleid het belang van sociale innovatie aan voor het innovatievermogen van de topsectoren (Kabinet, 2011, p. 18). De Adviesraad voor het Wetenschapsen Technologiebeleid signaleert het belang van sociale innovatie en adviseert de regering om kennisdeling en kruisbestuiving tussen sectoren te stimuleren (AWT, 2011, pp. 59-61). De Kamer van Koophandel Nederland heeft sociale innovatie opgenomen in de Nationale Agenda 2012 (Kamer van Koophandel, 2011). Vele bedrijven en adviesbureaus zijn met implementatie bezig.

Echter, het onderzoek blijft bij deze ontwikkelingen achter. Voortgang zou kunnen worden gemaakt als een open discussie tussen de verschillende onderzoeksgroepen alsnog van de grond zou komen. Misschien kunnen de Vlaamse collega's van de KU Leuven daarin een rol spelen. Zij hebben een goed theoretisch kader voor sociale innovatie ontwikkeld (Hootegem et al., 2008) en krijgen hopelijk de gelegenheid grootschalig onderzoek te doen naar de effecten van het Flanders 
Synergy programma. Ook in Vlaanderen is sociale innovatie een aspect van het industriebeleid en is de directeur van het Vlaamse centrum voor sociale innovatie zelfs lid van de pas geïnstalleerde Industrieraad. Kan het onlangs opgerichte Nederlands-Vlaamse 'Ulbo de Sitter kennisinstituut' ('het nieuwe organiseren') de handschoen oppakken? Eén van de uitdagingen is om de kwaliteit van het onderzoek te verbeteren. Daarbij is het zinnig om gegevens op organisatieniveau te koppelen aan gegevens op medewerkersniveau. TNO zou haar WEA dan kunnen proberen te koppelen aan de NEA (Nationale Enquête Arbeidsomstandigheden, Koppes et al., 2011). Hierdoor zou de 'kwaliteit van de arbeid' een serieuze plek krijgen in het onderzoek.

Sociale innovatie en het nieuwe werken blijken niet slechts een 'hype' te zijn en zich ook - sommigen zeggen 'juist' - in crisistijd verder uit te breiden. Dat is een extra reden om meer en beter onderzoek van de grond te krijgen.

\section{Noten}

1 De Resource Based View (RBV) is een stroming binnen het strategische management die eind jaren ' 80 is ontstaan. De RBV beschouwt ondernemingen als een verzameling van materiële en immateriële activa en capaciteiten.

2 Gezien de huidige media-aandacht voor fraude in wetenschappelijk onderzoek hecht ik eraan te zeggen dat die kwaliteit niet bij voorbaat wordt betwijfeld.

\section{Literatuur}

Alexiev, A., Jansen, J., Bosch, F. van den \& Volberda, H. (2010). Top management team advice seeking and exploratory innovation: the moderating role of TMT heterogeneity. Journal of Management Studies, 47, 1343-1364.

AWT (2011). Scherp aan de wind. Handvat voor een Europese strategie voor Nederlandse (top)sectoren. Den Haag: AWT.

Bolwijn, P.T. \& Kumpe, T. (1986). Toward the factory of the future. The MacKinsey Quarterly, Spring, 40-49.

Bolwijn, P.T., Breukelen, Q.H. van, Brinkman, S. \& Kumpe, T. (1986). Flexible manufacturing: integrating technological and social innovation. Amsterdam: Elsevier.

Bruin, G. de, Donners, M.,Vermeulen, B. \& Peltzer, F. (2004). Aan de slag met slimmer werken. Haarlem, Houten, Culemborg, Utrecht: AWVN, CNV BedrijvenBond, De Unie, FNV Bondgenoten.

Bureau Bartels (2011). Evaluatie tijdvak 1 actie E sociale innovatie van het ESF-programma 2007-2013. Amersfoort: Bureau Bartels B.V.

Burns, T.E. \& Stalker, G.M. (1961). The management of innovation. London: Tavistock Publications.

Delery, J.E. \& Doty, D.H. (1996). Modes of theorizing in strategic human resources management: tests of universalistic, contingency, and configurational performance predictions. The Academy of Management Journal, 39, 802-835.

Eeckelaert, L., Dhondt, S., Oeij, P., Pot, F., Nicolescu, G.I., Webster, J. \& Elsler, D. (2012). Review of workplace innovation and its relation with occupational safety and health. Bilbao: European Agency for Safety and Health at Work (forthcoming). 
EESC (European Economic and Social Committee) (2011). Innovative workplaces as a source of productivity and quality jobs. Brussels: EESC.

Erasmus Universiteit (2009). Erasmus Concurrentie en Innovatie Monitor 2008-2009. Rotterdam: INSCOPE/RSM/EUR.

Erasmus Universiteit (2010). Sociale innovatie: nu nog beter! Erasmus Concurrentie en Innovatie Monitor 2009-2010. Rotterdam: INSCOPE/RSM/EUR.

European Commission (2010a). Social innovation as part of the Europe 2020 strategy. Brussels: Bureau of European Policy Advisers.

European Commission (2010b). Proposal for a Council Decision on guidelines for the employment policies of the Member States. Part II of the Europe 2020 Integrated Guidelines. Brussels: COM92010) 193/3.

European Commission (2010c). Accompanying document to the Europe 2020 Flagship Initiative Innovation Union. Brussels: COM(2010)546/ SEC(2010)1161 final.

Hauw, P.A. van der, Pasaribu, M.N. \& Zeijden, P.T. (2009). Slimmer werken: gebruik, mogelijkheden en opbrengsten in de praktijk. Zoetermeer: EIM.

Hootegem, G. van, Amelsfoort, P. van, Beek, G. van \& Huys, R. (2008). Anders organiseren en beter werken: Handboek sociale innovatie en verandermanagement. Leuven/Voorburg: Acco.

Jongkind, R., Oeij, P.R.A. \& Vaas, S. (2003). Slimmer werken in productieve en gezonde banen. Hoofddorp: TNO Arbeid.

Kabinet (2011). Naar de top. Het bedrijvenbeleid in actie(s). Den Haag: Kabinet.

Kamer van Koophandel Nederland (2011). Nationale Agenda 2012. Den Haag: Kamer van Koophandel Nederland.

Karasek, R.A. (1978). A stress-management model of job strain. Revised Working Paper. Swedish Institute for Social Research.

Karasek, R.A. \& Theorell, T. (1990). Healthy work; stress, productivity and the reconstruction of working life. New York: Basic Books.

Koppes, L.L.J. et al. (2011). Nationale enquête arbeidsomstandigheden 2010. Methodologie en globale resultaten. Hoofddorp: TNO.

Lammers, C.J. (1967). Power and participation in decision-making in formal organizations. The American Journal of Sociology, 73, 201-216.

Leijnse, F. (2002). Het nieuwe werken. Den Haag: Ministerie van Economische Zaken.

Looise, J.C. (1996). Sociale innovatie moet, maar hoe? Rede. Enschede: Universiteit Twente.

Looise, J.C. \& Nijhof, A. (2006). Sociale innovatie in Nederland: methodieken om de rol van medewerkers in innovatie te versterken. Personeelsbeleid (december).

Meer, M. van der, Gemmeke, M. \& Dekker, H.S. (2008). Slimmer werken. Over de betekenis van slimmer werken voor het primair en voortgezet onderwijs. Den Haag: SBO.

Nauta, A., Oeij, P., Huiskamp, R. \& Goudswaard, A. (2007). Loven en bieden over werk: naar dialoog en maatwerk in de arbeidsrelatie. Assen: Van Gorcum.

Nauta, A. (2011). Tango op de werkvloer. Een nieuwe kijk op arbeidsrelaties. Assen: Van Gorcum.

Netwerk Onderwijsinnovatie (2010). Onderwijs kan zoveel slimmer. Den Haag: Ministerie van OCW.

OECD (2010). Innovative workplaces. Making better use of skills within organisations. Paris: OECD.

Oeij, P., Dorenbosch, L., Klein Hesselink, J. \& Vaas, F. (2010a). Slimmer werken en sociale innovatie. Integrale organisatievernieuwing. Den Haag: Boom Lemma.

Oeij, P., Kraan, K. \& Vaas, F. (2010b). Naar een wetenschappelijke onderbouwing van sociale innovatie. Tijdschrift voor HRM, 13, 1, 74-100. 
Oeij, P.R.A., Vroome, E.M.M. de, Kraan. K. \& Goudswaard, A. (2011). Werkgevers Enquête Arbeid 2010: methodologie en beschrijvende resultaten. Hoofddorp: TNO.

Oeij, P., Dhondt, S. \& Korver, T. (2011). Social innovation, workplace innovation and social quality. International Journal of Social Quality, 1, 2, 31-49.

Peeters, M.H.H. \& Pot, F.D. (1991). Sociale innovatie bij CTA. Leiden: NIPG TNO.

Pot, F.D. \& Koningsveld, E.A.P. (2009). Quality of working life and organizational performance. Two sides of the same coin? Scandinavian Journal of Work, Environment \& Health, 35, 421-428.

Pot, F., Xavier, M. \& Peltzer, F. (2008). Sociale innovatie en de rol van sociale partners. In S. Dhondt \& F. Vaas (red.), Waardevol werk. Van arbeidskwaliteit naar sociale innovatie (pp. 19-38). Den Haag: Lemma.

Pot, F.D. (2011). Workplace innovation for better jobs and performance. International Journal of Productivity and Performance Management, 60 (4), 404-415.

Pot, F., Dhondt, S. \& Oeij, P. (2012). Social innovation of work and employment. In H-W. Franz \& J. Hochgerner (Eds.), Challenge Social Innovation. Berlin: Springer (forthcoming).

Projectgroep Welzijn bij de Arbeid (1989). Functieverbetering en organisatie van de arbeid. Den Haag: Ministerie van Sociale Zaken en Werkgelegenheid.

Prud'homme van Reine, P. \& Dankbaar, B. (2009). Mythe en realiteit van het creëren van innovatieculturen. $M \& O, 3,45-59$.

Ramstad, E. (2009). Promoting performance and the quality of working life simultaneously. International Journal of Productivity and Performance Management, 58, 423-436.

SER (2006). Welvaartsgroei voor en door iedereen. Thema sociale innovatie. Den Haag: SER.

Sitter, L.U. de (1981). Op weg naar nieuwe fabrieken en kantoren. Deventer: Kluwer.

Sitter, L.U. de (1986). Technische ontwikkeling, organisatie en kwaliteit van de arbeid. In V.C. Vrooland (red.), Sociale innovatie en automatisering. Naar doelmatigheid en kwaliteit van de arbeid (pp. 15-23). Amsterdam: CCOZ.

Stichting van de Arbeid (2005). Op weg naar een meer productieve economie. Den Haag: STAR.

Taskforce Sociale Innovatie (2005). Sociale innovatie. De andere dimensie. Den Haag: Ministerie van Economische Zaken.

Totterdill, P., Exton, O., Exton, R. \& Sherrin, J. (2009). Workplace innovation policies in European countries. Nottingham: UKWON.

Vaas, F. (2001). Arbeidsproductiviteit verhogen door slimmer werken. Christen Democratische Verkenningen, 7/8/9, 26-32.

Vaccaro, G., Jansen, J., Bosch, F. van den \& Volberda, H. (2012). Management innovation and leadership: the moderating role of organizational size. Journal of Management Studies, 49, 1, 28-51.

Vink, P. (2002). Comfortabel en slimmer werken. Zeist: Kerckebosch.

Volberda, H.W., Vaas, F., Visser, J. \& Leijnse, F. (2005). Maatschappelijk topinstituut sociale innovatie. Erasmus Universiteit, Universiteit van Amsterdam, TNO, Innovatieplatform.

Volberda, H.W., Bosch, F.A.J. van den \& Jansen, J.J.P. (2006). Slim managen \& innovatief organiseren. Rotterdam: Eiffel.

Volberda, H., Jansen, J., Tempelaar, M. \& Heij, K. (2011). Monitoren van sociale innovatie: slimmer werken, dynamisch managen en flexibel organiseren. Tijdschrift voor HRM, $14,85-110$.

Vrooland, V.C (red.) (1986). Sociale innovatie en automatisering. Naar doelmatigheid en kwaliteit van de arbeid. Amsterdam: CCOZ. 
Winnubst, M., Linden, B. van der \& Kok, J. de (2011). Haalbaarheidsonderzoek monitor sociale innovatie. Zoetermeer: EIM.

Woude, M.A. van der (gastredacteur) (1982). Themanummer: Naar een vernieuwing van produktie-organisaties. Bijdragen naar aanleiding van de WRR-studie van L.U. de Sitter. $M \& O, 36,3$.

Zorginnovatieplatform (2009). Zorg voor mensen, mensen voor de zorg. Arbeidsmarktbeleid voor de zorgsector richting 2025. Den Haag: Zorginnovatieplatform. 